\title{
Érted jöttünk, nem ellened
}

\section{Szalai Gábor László}

\author{
Szent Angéla Ferences Általános Iskola és Gimnázium \\ igazgatója \\ gabor@szentangela.hu
}

DOI: 10.37205/TEL-hun.2019.3-4.08

Közoktatási intézményben dolgozva természetesnek tűnik, hogy hatalmas erőfeszítéseket teszünk, amikor új diákok közösségbe illesztésén dolgozunk, tanulókat integrálunk, kezeljük az ebből fakadó konfliktusokat. Ezen tevékenységek közben értekezleteket tartunk, szaktanár és osztályfönök közösen munkálkodik, bevonva a fejlesztőpedagógust, iskolapszichológust, szociális segítőt, és persze még folytathatnánk a sort.

Meglepő ugyanakkor, hogy ehhez képest mennyire szegényebb eszköztárral rendelkezünk egy kolléga megsegítésekor. Nem állítom, hogy intézményünkben ezt a fájó hiányt a tervszerü cselekvés eredményeképpen sikerült teljesen megszüntetni, de mára pedagógusaink a fenntartó jóvoltából nemcsak egy szemléletformáló és saját működésüket tudatosító képzésben vehetnek részt, vagy egy mentálhigiénés szolgálat segítségét vehetik igénybe, hanem két - egy kolléga és egy külső szakértő - mentor tanácsát is kikérhetik.

Sajnos, a lehetőségek megteremtése még korántsem elégséges, amit egy friss élményem is jól példáz. Megkértek ugyanis, hogy ősszel szakvizsgára készülő hallgatóknak tartsak iskolai gyakorlatot. Örömmel tettem eleget a felkérésnek, és megpróbáltam átadni azt az általunk képviselt szemléletmódot, amely egyre erőteljesebben épít az iskolai munkatársak közötti kooperációra. Számítottam ugyan rá, mégis megdöbbentett, hogy az ország különböző részeiből érkezett kollégák milyen nagymértékben egyetértettek abban, hogy a számos önként vagy kényszerből vállalt feladat jelentette túlterheléssel egyedül, magányosan kell megküzdeniük. Eközben a támogatás sokszor a közvetlen környezetben is elérhető lenne, mégis kihasználatlan marad.

Úgy gondolom, ez a „magányos harcos” szerep valóban jellemző ránk, pedagógusokra, amiben megerősít minket, hogy időnk túlnyomó részét valóban „egyedül töltjük a diákokkal”. Ebből következően válik lételemünkké az is, hogy nekünk 
mindig igazunk van, hiszen általában a tanulóknál szélesebb körű ismeretekkel rendelkezünk.

Ez így természetesen semmiképpen sem tudományos értékủ megállapítás, sokkal inkább sommás vélemény, de eddigi tapasztalataim alapján ez a két tényező nehezíti meg leginkább a segítségkérést, tesz minket zárttá mások véleménye, tanácsa iránt.

Pedig erre az együttműködésre sokaknak szüksége lenne. Örvendetesnek tartom a tényt, hogy az osztatlan, kétszakos képzésben részt vevő hallgatók lényegében egy gyakorlati évet töltenek az intézményekben (és azt is, hogy ez beleszámít a gyakornoki idejükbe). Emellett azonban jól látható, hogy munkavállalóként is igénylik a segítséget. Nem feltétlenül a módszertani, pedagógiai ismeretek terén, hanem például a tanári szerepben való eligazodás, váratlan pedagógiai szituációkra való reagálás tekintetében. De akár életvezetési kérdések is felmerülhetnek, hiszen egy kezdő tanárnak sokszor nehézséget okoz a magánélet és a heti húsz tanórára való lelkiismeretes felkészülés közötti egyensúly megteremtése.

Segítségre azonban nemcsak ez a csoport szorulhat. Ugyanúgy gondban lehet az a tapasztalt kolléga, aki másik intézményből kerül hozzánk, és éppen csak ismerkedik az iskola ethoszával, alapvető dokumentumaival, hagyományaival, szokásrendszerével. Még érdekesebb, amikor valaki hosszabb szünet után tér vissza a tanításhoz, miközben az általa korábban jól ismert intézmény haladt tovább a saját útján, és 5-10 év távlatából már nehéz a korábbi tapasztalatokra támaszkodni. Mások a kiégésnek azon a fokán állnak, ahol még egy-egy új impulzus is sokat segíthet a folyamat visszafordításában.

Egy kórház sürgősségi osztályán bizonyára tudnák, hogyan osztályozzák a „sebesülteket", kinek milyen kezelésre van szüksége, ki várhat a sorára. Egy intézményvezetőnek azonban még ahhoz is komoly erőforrások kellenek, hogy egyáltalán felismerje, kinek van szüksége segítségre, de utána is főhet a feje, amikor a továbblépés irányát kell meghatároznia. Általában ekkor szokott képbe kerülni egy mentortanár, akit széles spektrumú antibiotikumként terveznek bevetni (és ha szerencséje van, a pedagógusok immunrendszere nem ellenőrként azonosítja őt, és kezdi meg ellene azonnal a védekezést).

Azért is csábító lehet ez a megoldás, mert viszonylag még ehhez a legkedvezőbbek a körülmények. Az emelkedő anyagi juttatások reményében minden tantestületben vannak, akik harcba szállnak a mesterpedagógusi minősítésért, és gyakorlatvezető mentortanárnak lenni talán még a jobb lehetőségek közé tartozik. 
Emellett az állam normatív támogatásban is részesíti azokat az intézményeket, amelyek mesterpedagógust foglalkoztatnak, bár az ezzel járó órakedvezményt az iskolának kell megoldania.

De mi legyen, ha nem csupán „megúszós” megoldásként szeretnénk ehhez az eszközhöz folyamodni? Mitől lesz sikeres egy iskolai mentorrendszer? Nem vagyok biztos abban, hogy erre általánosan használható jó választ lehetne adni. Sőt, tapasztalataim szerint legtöbbször nem valamilyen eljárás, technika hangzik el megoldásként, hanem az válik kulcskérdéssé, hogy ki alkalmas a fentebb felsorolt csoportokkal való sikeres együttműködésre. És itt elsősorban nem a szakmai felkészültségre, a mentortanári tapasztalatra gondolok, inkább az emberi tényezőkre. Ahogy ugyanis egy diák sokkal eredményesebb lesz, ha a tanárával szemben pozitív attitűdökkel rendelkezik, ugyanúgy a mentortanárnak is közös hullámhosszt kell találnia mentoráltjával. Annál is inkább, mert sokszor az adott kolléga legbensőbb meggyőződéseivel (avagy leginkább elfojtott kételyeivel) kell szembenéznie, és a probléma nagyságával arányosan növekvő távolságot leküzdenie.

Ebből fakadóan hasznos lehet, ha egy intézményben több mentortanár is van. Saját praxisomban is előfordult, hogy a mentorálás alatt álló pedagógus nem találta meg a hangot pártfogójával, de új lendületet kapott egy másik kollégával való együttműködésnek köszönhetően.

Ahogy említettem, nálunk egy külső és egy belső mentor is dolgozik. Előbbi teljes felméréssel kezd, elbeszélget a pedagógussal, órákat látogat, és minden diákcsoporttal kérdőívet töltet ki. Ezután közli észrevételeit a vizsgált féllel, és amennyiben szükséges - felajánlja a mentorálási folyamatban való részvételét. Ez azonban csak önkéntes lehet, még akkor is, ha a vizsgálat eredményeinek sarokpontjairól az intézményvezető is értesül, és szemöldökét összevonva néz a segítséget elutasító pedagógusra.

Belső mentorunk ötéves mentorprogramját hajtja végre, ennek megfelelően tervezetten von be újabb és újabb kollégákat a folyamatba, és az egyes csoportokat egy rájuk szabott folyamaton visz végig. Ebbe körön kívülről szintén csak önkéntesen lehet bekerülni, ahol a mentorálás klasszikus elemei kerülnek terítékre.

Magam tapasztalom, hogy mindkét módszer eredményes lehet, noha a szereplők között nincs alá-fölé rendeltségi viszony. Így viszont a mentortanár legerősebb eszköze az a precíz helyzetkép, amely pontos tükröt tart a mentorált elé, erősségei felfedezésével „megemeli” az adott pedagógust, ugyanakkor elkerülhetetlenné teszi a hibáival való szembesülést is. Utóbbi esetben ugyan először gyakran találko- 
zom a tagadás jelenségével, a módszertan megkérdőjelezésével vagy egyéb kifogásokkal, később azonban mindez általában együttműködésbe fordul át (bár legtöbbször a másik mentorral). Ez természetesen kívánatossá teszi a mentorok szoros együttműködését is.

A tanárhiány ellenére is felmerülhet, hogy minek vesződni menorálással, amikor az intézményvezetőknek lehetősége van „posztra is igazolni”. Talán még meg is fontolnám ennek az állításnak az igazságtartalmát, ha nem hinném, hogy a mentorálás könnyen túlmutathat önmagán. Egyrészt jó üzenetet hordozhat a közösség számára, amely egyik tagját sem hagyja hátra (bár azzal az illúzióval is érdemes lenne leszámolni, hogy mindegyik pedagógus megmenthető). Másrészt nemcsak egy-egy kolléga fejlődését segítheti, hanem első pozitív tapasztalatként, „kapudroggá” válva hozzájárulhat a segítségadás és a segítség elfogadása kultúrájának kialakulásához. Ez a megosztás pedig sokat szelídíthet azon a szakmai, intézményi hierarchián, amely esetenként megnehezíti a személyes és/vagy iskolai fejlődést.

Ezek persze nem szükségszerű következmények, inkább elvárások, remények. Ám ha csak egy részük is beteljesül a mentortanároknak köszönhetően, már érdemes sokkal tudatosabban gondolkodnunk az ő szerepükről és rendszerben elfoglalt helyükről. 